\title{
Goat Management Systems in Bulathkohupitiya Veterinary Range
}

\author{
R.A.U.K. Wijethunga, Sujatha Premaratne ${ }^{1 *}$ and B.L.Peiris ${ }^{2}$ \\ Postgraduate Institute of Agriculture \\ University of Peradeniya \\ Sri Lanka
}

\begin{abstract}
The main objective of the present study was to identify the prospects and constraints to improve the economic productivity of goat herds in Bulathkohupitiya veterinary range. A survey was conducted using 82 farmers from two different management systems, namely intensive and extensive management systems. Data on religion of farmers, education level of farmers, herd size, herd composition, birth weight, slaughter weight, slaughter age, breeds, feeding, and cost and returns of raising goats were collected over a period of 3 months. Data were analyzed using the statistical software SAS ${ }^{\circledR}$. The results of the survey indicated that almost all farmers in the area considered goat farming as a part time business. Women played a major role in goat farming in the area, including feeding and management of goats. Goat farming is a traditional activity in Hindu and Muslim communities, where $92.8 \%$ of Hindus contributed to mutton industry. Between the two management systems, the average herd size of extensive management systems (13.1 AU/farm) was significantly greater $(p<0.05)$ than intensive systems $(6.8$ AU/farm). The results revealed that birth weight, slaughter weight and growth rate under intensive management system were significantly greater $(p<0.05)$ compared to extensive system. The average monthly profit was significantly lower $(p<0.05)$ under intensive management system compared to extensive management system because of high costs in feeding and labour involvement in intensive system. Therefore, it can be concluded that goat farming under extensive management system was more profitable compared to intensive management system in Bulathkohupitiya Veterinary Range.
\end{abstract}

Keywords: Goat management systems, herd characteristics, mutton production

\section{INTRODUCTION}

Livestock is an important component in small holder agricultural pursuits in all agro ecological zones in Sri Lanka. In rural mixed farm enterprises, most small holder farmers are engaged in crop production as the primary agricultural activity but also rear few goats with minimal cost. In traditional management system, the goats are fed on fodder resources on communal lands, scrub land reservations and paddy lands. Animals are left for grazing during the day time and headed back home in the evening. The goat industry has a vast potential to develop the economy of Sri Lanka yet it is still growing at a slow rate. The total annual domestic production of mutton was 1.69 MT in year 2011 (Department of Census and Statistics, 2011). Yet the value contributed to rural households is quite significant because livestock is still one of the most affordable and sustainable ways of enhancing rural

\footnotetext{
Department of Animal Science, Faculty of Agriculture, University of Peradeniya, Sri Lanka

2 Department of Crop Science, Faculty of Agriculture, University of Peradeniya, Sri Lanka

Corresponding author: ruwanga: suep@pdn.ac.lk
} 
household income and it contributes to the economic development of the country. Though the demand for mutton has increased dramatically during the last decade, the country is producing only 1.69 MT in year 2011 and the balance requirement is imported. Therefore, importation of mutton costs 62.34 million rupees annually (Sri Lanka Customs Report, 2011). Goat farming is one of the popular agricultural activities in Bulathkohupitiya veterinary range and the objective of the present study was to compare goat management systems in Bulathkohupitiya Veterinary Range so that recommendations could be given to improve the production in the area.

\section{METHODOLOGY}

Location: The study was conducted in Bulathkohupitiya Veterinary range which is located in low country wet zone. Altitude of the area ranges from 1500-2000 $\mathrm{m}$ above the sea level whereas the average rainfall in the study area was $2500-5000 \mathrm{~mm}$ per year.

Data collection: According to the information available with the Veterinary office there were 265 registered goat farms with 1259 goats in the 27 gramaniladari divisions in Bulathkohupitiya veterinary range and small scale goat farmers in the region contributed significantly to domestic meat production in the district (District Veterinary Office Report, 2011). The study was conducted using small scale farmers, who are rearing goats in 4 estates in four gramaniladari divisions namely Kiriporuwa, Adurapola, Urumeewala and Yatideriya in Bulathkohupitiya veterinary range. According to the information available with the Veterinary office, there were 153 registered goat farms having 952 goats in these 4 gramaniladari divisions. The farmers of extensive management system were selected at random whereas all the intensive farmers in four estates were used for the survey. Extensive management system was popular in the area. Therefore, 67 farmers were selected under the extensive management system and all (15) farmers were selected from the intensive management system (31\% of the total farmer population in Bulathkohupitiya veterinary range). Data were collected using a pre-tested structured questionnaire which had the following information: owners general information, herd size, herd composition, available breeds, management system, breeding method, birth weight, slaughter weight, slaughter age, cost and income details during the period from January to April 2011. Each respondent was given a brief description about the nature and purpose of the study at the beginning of the interview. Responses of farmers were recorded directly on the questionnaires.

Data analysis: The data were analyzed by the statistical software $\mathrm{SAS}^{\circledR}$ using the SAS procedures; univariate, frequency and general linear models (GLM) (SAS, 1996). Mean comparisons were done by the Least Significant Difference (LSD) wherever appropriate.

\section{RESULTS AND DISCUSSION}

\section{Socio economics of small holder goat farmers}

According to the results, $93 \%$ of the goat farmers were Hindu and $7 \%$ of farmers were Muslim in the area (Table 1). Goats were not reared for meat production by Buddhist people due to religious barriers. Abegunawardena and Amarasekera, (1995) also reported similar results. However, Serasinhe and Marapana (2011) reported that Buddhists dominated in goat rearing for selling live goats for meat production in the Southern Province of Sri Lanka. Goat farming was a part time business for many farmers in these four gramaniladari divisions and 
most of them were engaged as labourers in rubber or tea plantations. They were traditional farmers but a low interest was shown on goat farming because of the low income. Women played a major role in goat farming in the area, including feeding and management of goats as well as looking after the children in their family. Nearly $52 \%$ of farmers were educated up to grade 5 , while $41 \%$ were educated up to grade 10 and, only $7 \%$ were up to G.C.E. (O/L) in the study area indicating that highest percentage of farmers was educated up to primary level. Goat population in Bulathkohupitiya veterinary range was very heterogeneous. According to the survey, $75.6 \%$ of goats were of indigenous type, followed by $12 \%$ Jamunapari, $4.8 \%$ Jamunapari cross and $7.3 \%$ of Sannan. Most popular goat breed in the region was indigenous type and they were extensively managed, while other breeds were reared intensively. Mahusoon and Sivarajah (1999), Mahusoon (1998) and Hariharan and Sivarajah (1993) also observed similar results in the coconut triangle and eastern region, respectively.

\section{Herd size and composition}

The mean herd size in Animal Units (AU) under extensive and intensive management systems were 13.1 and $6.08 \mathrm{AU} /$ farm, respectively (Table 2) and the means are significantly different $(\mathrm{p}<0.05)$. Numbers of female goats and Billy goats in extensive management system were significantly greater $(\mathrm{p}<0.05)$ compared to those in intensive system (Table 2$)$. This is mainly due to the non-availability of land under intensive goat management system. Percentage of Billy goats in the herd was less compared to female goats under both management systems because excess male animals were sold to fulfil household requirements. A limited number of Billy goats were kept for the breeding purposes of the herd.

Table 1. General observations of goat farmers in Bulathkohupitiya Veterinary Range

\begin{tabular}{ll}
\hline Variable & Percentage \\
\hline Religion & \\
Hindu & 92.8 \\
Muslim & 7.2 \\
Education level & \\
Grade 1 - 5 & 52 \\
Grade 5 - 10 & 41 \\
G.C.E. (O/L ) & 7 \\
G.C.E. ( A/L ) & - \\
Higher Education & - \\
Breed of goats & \\
Jamunapari & 12 \\
Jamunapari cross & 4.8 \\
Saanan & 7.3 \\
Indigenous & 75.6 \\
Management practice & \\
Extensive & 81.7 \\
Intensive & 18.2 \\
\hline
\end{tabular}


Table 2. Average herd size and composition of goats under different management systems in Bulathkohupitiya Veterinary Range ${ }^{\dagger, \dagger \dagger}$

\begin{tabular}{lcc}
\hline \multicolumn{1}{c}{ Variable } & \multicolumn{2}{c}{ Management system } \\
\cline { 2 - 3 } & Extensive & Intensive \\
\hline Herd size & $13.1^{\mathrm{a}} \pm 0.15$ & $6.08^{\mathrm{b}} \pm 0.11$ \\
Billy goats (male) & $5.73^{\mathrm{a}} \pm 0.69$ & $2.11^{\mathrm{b}} \pm 0.71$ \\
Dairy goats (female) & $7.04^{\mathrm{a}} \pm 0.13$ & $4.45^{\mathrm{b}} \pm 0.02$ \\
Kids & $0.33^{\mathrm{a}} \pm 0.02$ & $0.24^{\mathrm{a}} \pm 0.04$ \\
\hline
\end{tabular}

Mean $\pm \mathrm{SE}, 1 \mathrm{AU}=35 \mathrm{~kg}$ animal, Weaned kids to yearlings $=0.6 \mathrm{AU}$, Does $=1 \mathrm{AU}$,

Does with or without kids $=1 \mathrm{AU}$, Mature bucks $=1.3 \mathrm{AU}$

${ }^{\dagger \dagger}$ Means within a row with the same letter are not significantly different $(\mathrm{p}>0.05)$.

\section{Effect of farm management system on birth weight, growth rate and slaughter weight of goats}

According to the study goats under intensive management system had significantly greater $(p<0.05)$ birth weight compared to extensive management system (Table 3$)$. Birth weight of kids under extensive management system was $20 \%$ significantly lower $(\mathrm{p}<0.05)$ than that of intensive management system and this may be related with the poor feeding and management practices used under extensive management system. Furthermore, goats under extensive management system were mainly of indigenous type whereas indigenous type, Jamunapari and Sanan were used under intensive management system. This could also have an effect on the lower birth weight of kids under extensive management system compared to intensive management system. According to Abegunawardena and Amarasekera, (1995), average birth weight of Boer, Boer crosses, Jamunapari and Jamunapari crosses was ranging from 1.5 to $2 \mathrm{~kg}$. The reason for poor birth weights observed in the present study might be related to the specific area used in the present study which comprised of Bulathkohupitiya Veterinary Range compared to whole of the country in the study by Abegunawardena and Amarasekera, (1995). Furthermore, slaughter weight of goats under intensive management system was 5\% greater $(\mathrm{p}<0.05)$ than the extensive management system even though the slaughter age was 5 months less than that of extensive management system.

Growth rate of kids under extensive management system was $527 \mathrm{~g}$ per month where as a value of $671 \mathrm{~g}$ per month was observed under intensive management system which is almost $24 \%$ greater $(\mathrm{p}<0.05)$ compared to extensive management system. The reason for this may be that nutritive value of fodder consumed by goats under extensive management system was poor compared to intensively managed goats. Goats managed under intensive system received some amount of concentrates from the diet and, quality and quantity of fodder was somewhat uniform throughout the growing period. Therefore mean slaughter age of goats under intensive management system was 5 months less compared to extensive management system. Profit margin under extensive management system was significantly greater $(p<0.05)$ compared to intensive management system due to less expenditure on feeding and management of goats.

Goat meat industry is very popular in the area due to low usage of resources and higher profits gained compared to the goat milk industry. The market price of live animals ranged from Rs. 360 to 440 per $\mathrm{kg}$ due to interference from middlemen. According to Seresinhe and Marapana (2011) the farm gate price of a live animal in Hambantota district ranged from Rs. 
180 to 300 whereas Rs. 350 to 550 was reported from Matara district in Sri Lanka. The middlemen have a significant impact on this highly fluctuating farm gate price. A few farmers used goat manure for their own cultivation or sold the manure to vegetable farmers to generate an additional income. A $50 \mathrm{~kg}$ bag of goat manure was sold for Rs. 100 in the area.

Table 3. Effect of management systems on performance of goats in Bulathkohupitiya Veterinary Range ${ }^{\dagger, \dagger \dagger}$

\begin{tabular}{lcc}
\hline \multicolumn{1}{c}{ Variables } & Extensive & Intensive \\
\hline Mean birth weight $(\mathrm{g})$ & $604.18^{\mathrm{a}} \pm 25.12$ & $754.00^{\mathrm{b}} \pm 74.14$ \\
Mean slaughter weight $(\mathrm{kg})$ & $29.75^{\mathrm{a}} \pm 0.46$ & $34.37^{\mathrm{b}} \pm 0.90$ \\
Mean growth rate $(\mathrm{g} /$ month) & $527.99^{\mathrm{a}} \pm 11.15$ & $671.63^{\mathrm{b}} \pm 32.67$ \\
Mean slaughter age (month) & $55.96^{\mathrm{a}} \pm 0.87$ & $50.93^{\mathrm{b}} \pm 1.51$ \\
Price of female (Rs) & $9422.39^{\mathrm{a}} \pm 637$ & $14300.00^{\mathrm{b}} \pm 1027$ \\
Price of male (Rs) & $12130.54^{\mathrm{a}} \pm 354$ & $17480.85^{\mathrm{b}} \pm 840$ \\
Income (Rs/kg) & $331.57^{\mathrm{a}} \pm 10.52$ & $424.89^{\mathrm{b}} \pm 13.54$ \\
Cost $(\mathrm{Rs} / \mathrm{kg})$ & $69.91^{\mathrm{a}} \pm 7.33$ & $123.45^{\mathrm{b}} \pm 11.93$ \\
Profit $(\mathrm{Rs} / \mathrm{kg})$ & $282.89^{\mathrm{a}} \pm 7.40$ & $309.08^{\mathrm{b}} \pm 10.37$ \\
\hline
\end{tabular}

${ }^{\dagger}$ Mean \pm SE

${ }^{\dagger \dagger}$ Means within a row with the same letter are not significantly different $(\mathrm{p}>0.05)$.

\section{Farm income}

The expenditure, monthly gross income and profit per farm under two management systems are presented in table 4.

Table 4. Meat production, income and expenditure of the goat farmers under extensive and intensive management systems per month ${ }^{\dagger, \dagger \dagger}$

\begin{tabular}{lcc}
\hline \multicolumn{1}{c}{ Variables } & Extensive & Intensive \\
\hline Income (Rs/herd/month) & & \\
Sale of animals & $9207^{\mathrm{a}} \pm 123$ & $11052^{\mathrm{b}} \pm 506$ \\
Sale of fertilizer & $798^{\mathrm{a}} \pm 23$ & $763^{\mathrm{a}} \pm 64$ \\
Total income & $23240.30^{\mathrm{a}} \pm 1402.82$ & $25866.67^{\mathrm{a}} \pm 2492.17$ \\
Expenditure (Rs/herd/month) & & \\
Concentrate & $1710^{\mathrm{a}} \pm 71$ & $2051^{\mathrm{a}} \pm 207$ \\
Mineral and De worming & $403^{\mathrm{a}} \pm 36$ & $512^{\mathrm{a}} \pm 75$ \\
Veterinary service & $250^{\mathrm{a}} \pm 12$ & $389^{\mathrm{b}} \pm 44$ \\
Hired labor & $1343^{\mathrm{a}} \pm 72$ & $3712^{\mathrm{b}} \pm 103$ \\
Family labor & $733^{\mathrm{a}} \pm 46$ & $1493^{\mathrm{b}} \pm 228$ \\
Artificial insemination & $197^{\mathrm{a}} \pm 12$ & $275^{\mathrm{b}} \pm 24$ \\
Total expenditure & $4761.43^{\mathrm{a}} \pm 551.95$ & $8224.33^{\mathrm{b}} \pm 1046.50$ \\
Net profit (Rs/herd/month) & $18824.67^{\mathrm{a}} \pm 884.99$ & $11846.87^{\mathrm{b}} \pm 1450.73$ \\
\hline Mean \pm SE & &
\end{tabular}

According to the study, the main income from goat farming was through selling of goats for meat and selling of goat manure as a fertilizer in the area and a higher income was generated by the intensively managed farms. The expenditure under both management systems 
consisted of cost of concentrate, minerals and de-worming, hired labour, family labour and artificial insemination. The results of the study indicated that the average total monthly expenditure per farm under extensive management system was Rs.3463 lower $(p<0.05)$ than intensively management system particularly due to significantly lower $(\mathrm{p}<0.05)$ labour costs. Although income was less, farmers in extensive management system reported a significantly higher $(\mathrm{p}<0.05)$ average profit margin per farm compared to those who have adapted intensive management system.

Non-availability of land under intensive management system and, low birth weight of kids under both management systems were the main constraints identified in the present study. In order to improve the goat production in Bulathkohupitiya Veterinary Range, following suggestions can be given; introduce more strategic feeding during the dry period, improvement of breeding using superior breeds of goats and improvement of health care facilities and proper marketing facilities to sell animals. Thus, it is important to educate the farmers on these aspects as well as scientific goat management in the study area to improve the productivity of goats.

\section{CONCLUSIONS}

Goat farming is an important source of income for the small scale goat farmers in Bulathkohupitiya veterinary range. Most of the farmers belong to the small scale category based on land availability, herd size, and mutton production. Small scale goat farming in Bulathkohupitiya range is carried out as a part time business rather than a full time business by housewives, children and elderly people. Majority of the farmers under extensive management system depended upon free grazing, as their main source of animal feed while some amount of concentrates was fed to goats under intensive management system. The average household income was higher in the intensive management system. However, monthly expenditure was also higher in the intensive system and therefore, net profit obtained under extensive management system was $5.57 \%$ higher than the intensive management system. Therefore, it can be concluded that goat farming under extensive management system was more profitable compared to intensive management system in the Bulathkohupitiya veterinary range.

\section{ACKNOWLEDGEMENTS}

The assistance given by the goat farmers in Bulathkohupitiya veterinary range and the contributions by the staff of Veterinary office of Bulathkohupitiya is greatly appreciated.

\section{REFERENCES}

Abegunawardena, H. and Amarasekara, S.K. (1995). Strategies for revitalizing the dairy Industry in Sri Lanka. Ceylon Vet. J., 25, 9 - 11.

Department of Census and Statistics (2011), Colombo, Sri Lanka.

District Veterinary Office Report (2011), Kegalle, Sri Lanka. 
Hariharan, R. and Sivarajah, P. (1993). Improving productivity of indigenous goat species through better management in Eastern Sri Lanka. Regional Animal Production and Health Commission of the FAO, Bangkok, Thailand. Asian Livestock, 18 (1).

Mahusoon, M.M. (1998). Evaluation of goat production systems in the Dry Intermediate zone of the coconut triangle of Sri Lanka. A thesis submitted in partial fulfillment for the degree of Master of Philosophy, PGIA, University of Peradeniya, Sri Lanka.

Mahusoon, M.M. and Sivarajah, P. (1999). Improving goat production in the "Coconut triangle" of Sri Lanka. AGRIEAST., 1(1), 67 - 74.

SAS (1996). SAS/STAT User's Guide. Version 6.12, SAS Institute Inc., Cary, North Carolina, USA.

Seresinhe, T. and Marapana, R.A.U.J. (2011). Goat farming systems in the Southern province of Sri Lanka: Feeding and Management Strategies. World J. Agric. Sci., 7(4), 383 390.

Sri Lanka Customs Report (2011), Colombo, Sri Lanka. 